Syracuse University

SURFACE

\title{
Sport Sovereignty at Bay: The Impact of Globalization and the Multi-National Sport Enterprise on the Westphalian-Based International Sport Structure
}

\author{
Rick Burton \\ Syracuse University, rhburton@syr.edu \\ Matthew Robinson \\ Emir Turam
}

Follow this and additional works at: https://surface.syr.edu/researchcenter

Part of the Business Administration, Management, and Operations Commons, and the Sports Management Commons

\section{Recommended Citation}

Burton, Rick; Robinson, Matthew; and Turam, Emir, "Sport Sovereignty at Bay: The Impact of Globalization and the Multi-National Sport Enterprise on the Westphalian-Based International Sport Structure" (2011). College Research Center. 2.

https://surface.syr.edu/researchcenter/2

This Article is brought to you for free and open access by the David B. Falk College of Sport and Human Dynamics at SURFACE. It has been accepted for inclusion in College Research Center by an authorized administrator of SURFACE. For more information, please contact surface@syr.edu. 


\section{PROJECT MUSE}

Sport Sovereignty at Bay: The Impact of Globalization and the Multi-National Sport Enterprise on the Westphalian-Based International Sport Structure

Rick Burton

Matthew J. Robinson

Emir Turam

SAIS Review, Volume 31, Number 1, Winter-Spring 2011, pp. 31-38 (Article)

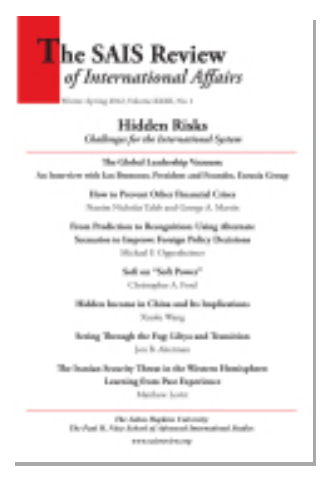

Published by The Johns Hopkins University Press

DOI: 10.1353/sais.2011.0004

$\Rightarrow$ For additional information about this article

http://muse.jhu.edu/journals/sais/summary/v031/31.1.burton.html 


\section{Sport Sovereignty at Bay: The} Impact of Globalization and the Multi-National Sport Enterprise on the Westphalian-Based International Sport Structure

\section{Rick Burton, Matthew J. Robinson, and Emir Turam}

\section{Introduction}

7 he existing framework for international sport is based on the guiding lia promoted sovereignty, self-determination, equality between states, and non-intervention of one state in the internal affairs of another state, and it has served as the basis for international relations for several centuries. Vernon observed that "the advanced world, carried ebulliently on the crest of a technological revolution in transportation and communication, has absentmindedly set up a virile system of international institutions and relationships that sit alongside the system of nation-states." Vernon's observation captures the essence of the existing international sport structure, where the nation state is the defining characteristic and criterion for membership in international sport organizations (for example, International Olympic Committee) and participation in international sporting events (for example, FIFA World Cup team inclusion, Olympic athlete inclusion).

Miller et al. argued that many have mistakenly predicted the demise of the nation-state and Westphalian sovereignty and the rise of international sovereignty over the past century, but admit that the nation-state has lost its potency and relevance and increasingly struggles to control the impact of cross-border flows stimulated by transnational forces. ${ }^{2}$ Challenges to

Richard Burton is the David B. Falk Distinguished Professor of Sport Management at Syracuse University; Matthew J. Robinson is an Associate Professor \& Director of Sport Management Program at the University of Delaware; and Emir Turam is the Director of International Relations for the Turkish Basketball Federation. 
Westphalian sovereignty in sport have increased with the growing power and influence of the Multinational Sport Enterprise (MNSE) and the forces of globalization. MNSEs are "international or cross-border entities which are of the existing interstate system firmly rooted in national territorial jurisdiction."3 Appadurai defined globalization as a series of diverse, fluid, and unpredictable flows that include the movement of capital, technology, people, and mediated images. ${ }^{4}$

Professional sport clubs such as the Los Angeles Lakers (basketball) and FC Barcelona (football) as well as the leagues of which they are members, the National Basketball Association and the Spanish La Liga respectively, are all in fact MNSEs. These organizations exemplify the forces of globalization influencing sport; when FC Barcelona won the Union of European Football Associations (UEFA) championship in 2009 playing a "European style" of football, only eleven of its twenty four players were Spanish. Its victory over English Premier League club, Manchester United, which was owned by an American, was viewed by 206 million people worldwide. Coupled with the attempts by athletes and countries to circumvent and/or benefit from eligibility requirements for Westphalian-based international sport competitions and the willingness of those events to offer MNSEs and athletes a global marketing platform, the Barcelona-Manchester United match was an illustration of the rise of the MNSE and globalized sports and a portent for the decline in the power and influence of the Westphalian-based sport structure.

\section{Challenging the Status Quo}

The Westphalian-based framework for international sport governance (Figure 1) was established in the early part of the twentieth century. Within this model, a country's athletes are organized under the national federation of each sport, and the national federations are under the international federations (these included FIFA, FIBA, etc.) as well as the National Olympic Committee for the country. Each of these entities is ultimately affiliated with the International Olympic Committee (IOC). Even though countries are connected by the IOC and each country's Olympic Committee and National Federation adheres to rules developed by international governing bodies, one country does not interfere in the sport decision and policy formation of other countries. An athlete must be a citizen in order to represent that country in an international competition. Is this model still relevant or has it become, as George W. Ball stated close to half a century ago in reference to the city-state, "a very old-fashioned idea and badly adapted to serve the needs of our present complex world?"5

Chappelet and Kubler-Mabbott have noted that the classical Olympic system described has already been influenced by MNSEs to create an extended Olympic system that includes national sponsors and media; leagues, professional athletes, and teams; international sponsors; and government and inter-governmental organizations (Figure 2). Broadcast revenues and corporate sponsorship through The Olympic Partner (TOP) program are the most significant source of revenue for the IOC, ${ }^{6}$ and professionals now 
compete in the Olympic Games. This increased role of MNSEs in the international sport structure has led to MNSE-paid participants protecting their economic interests (examples include fear of injury, undergoing medical procedure so to be ready for the professional season, loyalty to corporate sponsor, and being exhausted and/or injured competing for a club instead of preparing for an international competition) or enhancing those interests (for example, increasing exposure for sponsorship opportunities or securing larger contracts after excelling in an international event), as the impetus for participating more rather than to represent and promote the nation.

The IOC, whose members consist of over two hundred sovereign states, remains the preeminent organization in international sport and host of the Summer and Winter Olympic games while FIFA, the governing body of the world's most popular sport, hosts the world championship every four years. (Over 700 million viewers watched the 2010 final game between the national teams of Spain and the Netherlands.) However, international championships offered through the existing international sport governance structure (for example, UEFA Cup) and by MNSEs (for example, NBA Finals) have also presented global marketing opportunities for participants, MNSEs, and multinational corporations. Up to this point the two formats have been able to co-exist, but there has been conflict and the future may present more.

\section{The Athlete First}

A prominent example of an athlete putting his economic interests first was at the 1992 Barcelona Summer Olympics. American professional basketball player Michael Jordan demonstrated loyalty to his economic interests by prioritizing his endorsement deal with MNSE Nike over that of his country's Olympic Committee corporate sponsorship deal with rival MNSE Reebok. The ultimate irony was that Jordan used an American flag to hide the Reebok logo on the warm-up suit that all U.S. athletes were required to wear on the medal stand as part of the corporate sponsorship deal with Reebok. Jordan's U.S. teammate Charles Barkley, also a Nike endorser and who also covered the Reebok logo, summarized it best: "I have two million reasons why I won't wear Reebok.”

At the 2010 FIBA World Championships, another American basketball player refused to represent his country. Lebron James, who was instrumental in the U.S.' gold medal win at the 2008 Beijing Olympics, cited impending free agency and other business interests as reasons for his choice not to compete. Several of the players who represented the U.S. in the FIBA World Championship also considered the impact on their personal brand in deciding to try out and play for the U.S. team. Individual players discussed the potential to gain international exposure for both themselves as well as the NBA club in which they play. In one occasion, a player said that his NBA team was in a small market and did not include any endorsement deals; he had hoped his participation in the world championships would lead to endorsement opportunities. As an MNSE like the NBA continues to expand globally, there may be no need for players to participate in a Westphalian- 
based international competition to gain international exposure. Players can either play in expanded MNSE leagues and competitions or newly-created MNSE-based international competitions.

\section{The Impact of Migrants}

Another significant development within the realm of international sport that has led to the weakening of Westphalia-based system is the Bosman decision by the European Court of Justice in 1995. While athletes in the United States have enjoyed freedom of movement domestically through collective bargaining agreements between the players' unions and the leagues, the Bosman decision essentially expanded this freedom to European sport and specifically the premier sport of football. The Bosman decision revoked the quotas for football leagues within the European Union (EU) on the number of foreign players each team could sign. Quotas are still in effect, but they can only be used to limit the number of non-native EU players. After the Bosman decision, a player whose contract had expired was free to leave a club without paying a transfer fee and had more opportunities to sign elsewhere. Thus, players had more freedom in moving between clubs and countries to seek out the highest wages. This has led to the increase in player salaries over the past fifteen years and to the increasing trend of players playing in multiple countries during the course of their careers or even during the same season.

The freedom of movement of players among countries has led to dilemmas for both players and employers. An MNSE in one country may not be interested in having its star player participating for his native country within a Westphalian-based international competition, such as a FIFA World Cup qualifier or even a FIFA World Cup match. An athlete may want to represent his nation in an international event, but in many ways it contradicts his primary economic interest and the interests of the MNSE for which he plays. He could be injured in the event, which would be a detriment to the financial interests of the sport club (resulting in a losing season and a decrease in attendance) as well as to his own future earnings. Spanish basketball player Pau Gasol broke his foot at the 2006 FIBA World Championships and played twenty-one fewer games for his NBA team, the Memphis Grizzlies, in 2006-07 than he did in 2005-06; the team won twenty-seven fewer games during the 2006-07 season.

In 2010, Steven Gerrard, captain of the English Premier League Liverpool team, was injured in an international friendly between England and France and missed four weeks of the English Premier League (EPL) season. These types of situations intensify what Green termed the "club versus country" conflict. Green believes that EPL clubs, which are MNSEs, put their own interests ahead of the country's interest, not only in international competition but also in the development of youth players. ${ }^{7}$ Kuper and Szymanski noted that the majority of players who will represent the English in international competition play in the highly competitive EPL, so that when they do play internationally they are tired, hurt, and unfocused. They argue that 
England is moving towards becoming a second-class football power within the Westphalian-based sport structure, ${ }^{8}$ but Manchester United, Chelsea, and Arsenal have become top clubs globally by using native players along with an influx of non-native players. Green noted that in the 2008-09 EPL season it was common for $75 \%$ of the EPL clubs to start non-native players recruited away from other nations. ${ }^{9}$ While some say that citizens will reject the influx of foreign players, Kuper and Szymanski argued that fans prefer excellence over citizenship, as demonstrated by EPL record attendance and the fact that Arsenal, which in 2008-09 had an all-foreign roster and was coached by a Frenchman, drew over 60,000 fans per game. ${ }^{10}$ Kuper and Szymanski echo the sentiments of Silvio Berlusconi, who as owner of the AC Milan Football club stated that "the concept of the national team will gradually become less important. It is the club with which fans associate."11

\section{The Pursuit of Gold}

In the pursuit of medals or world championships, it is common practice for athletes and countries to attempt to circumvent the Westphalian-based system in a number of ways. In representing a nation one must be a citizen of that nation, but the citizenship question is ambiguous at best. What constitutes citizenship in one country may not constitute it in another. Also, the time and difficulty of acquiring citizenship varies. In 2008, American women's basketball player Becky Hammon played professionally in both the United States and in Russia. Although she was considered one of the top players in the Women's National Basketball Association (WNBA), she was not invited to try out for the U.S. women's national team. The Russian national team offered her a spot. Her passport application was rushed through by the government and she was able to represent Russia in the 2008 Olympic Games. A further benefit for Hammon, now a Russian citizen, and her Russian professional club, was that she would not count as one of two non-Russian players on the floor in Russian league games.

Dual citizenship gives some athletes additional choices. In the 2008 Olympic Games, Michael Phelps of the U.S. edged out Milorad Čavič of Serbia to win the gold medal in the 100-meter freestyle. Čavič was born in the United States and went to both high school and college in the U.S., but because he also had Serbian citizenship, he competed for Serbia in the Olympic Games. IfČavič had competed as an American, either he or Phelps might not have qualified for the Olympics, while an athlete from another nation with an inferior time would still have competed. In a sport where a hundreds of a second separate first from fourth place, Čavič played the averages to ensure he would square off with Phelps at the Olympic Finals and not the U.S. Olympic Trials finals.

Some countries also look to develop a sport in their country by importing athletes from another. For example, Turkey does not have internationally successful long distance runners. To address this, they imported Elvan Abeylegesse, an Ethiopian, who was able to run by acquiring dual citizenship. Abeylegesse is the Turkish and European record holder at 10,000 meters, 
and earned a silver medal in the Beijing Olympic Games in 2008, and the gold medal in the European Championship in 2010 for Turkey at the same distance. She runs under Turkish documentation, but how much could she count as Turkish in a social and cultural sense? How much can Turkey be proud of raising a champion?

Although there are certain restrictions on athletes representing a country of which they are not a citizen, there are no restrictions on coaches. In the 2010 FIFA World Cup, twelve of the thirty two national teams were coached by non-natives and five of the six nations from Africa had non-

It would be assumed that the rationale for hiring a non-native coach is to achieve better results, but Kuper and Syzmanski noted that another consequence has been the increase in the European/Continental style of play that mixes German discipline, Italian defense, and Dutch passing. This style of play has become dominant both in Europe and the world. native coaches. It would be assumed that the rationale for hiring a nonnative coach is to achieve better results, but Kuper and Syzmanski noted that another consequence has been the increase in the European/ Continental style of play that mixes German discipline, Italian defense,

and Dutch passing. This style of play has become dominant both in Europe and the world. ${ }^{12}$

To further enhance results, the recruitment of non-native players seems logical, but the existing rules on players' citizenship prohibit that from occurring with the same ease. Although the English were in dire need of an offensive threat in the 2010 FIFA World Cup, the existing structure prevented them from recruiting a skilled forward like Cote d'Ivoire native Didier Drogba to provide that skill set. Yet Chelsea, an MNSE, can recruit and sign Drogba.

In 2010, the Los Angeles Lakers won the National Basketball Association World Championship with three international players, a quarter of its active roster. Overall, NBA teams ended the 2009-10 season with seventy nine players from thirty five countries on their rosters. The Milwaukee Bucks had the most international players of any team that season with six, comprising nearly half of their fourteen-man roster. NBA Commissioner David Stern has been quoted in private conversations saying, "The NBA employs the best basketball players in the world, regardless of their nationalities." Along with the international presence on the court, the NBA Finals were broadcast in 215 countries and in forty-one languages. 


\section{Conclusion}

Korbin noted that sovereignty has become much more problematic and that globalization has compromised the basic idea of economic (and political) governance based on geographic jurisdiction. ${ }^{13}$ Although it may be easier to forego national concepts in search of higher profits, is society ready to do the same in erasing different cultural perceptions and evaluations, among them the unique and colorful traditions that nation-states have dating back many centuries? It must not be forgotten that the European Union, probably the most successful regional cooperation platform in the world, successfully created a combined economic platform but failed to do the same in cultural and legal aspects. One of the main reasons for the rejection of the European Constitution in national referendums was the importance laid upon the protection of cultural approaches.

Therefore the question remains, for future generations, will the more influential and important global event be a world club basketball championship final between the Los Angeles Lakers and Fenerbache of Turkey with a worldwide audience via multiple electronic media, where the nationality of both the athletes and fans from both clubs will be a side-note; or the FIFA World Cup Final between the U.S. and Turkey, where the rosters and the majority of the fans are limited to citizens of those respective countries? Future research should examine if the shift away from the Westphalian-based sport structure is occurring or may occur in the not too distant future. It would appear that the club event would be a demonstration of globalization and higher quality, and would be more tightly embraced by the global community. If this is the case, the future may see the days of national flag waving and national anthems being replaced by club banners and club fight songs by citizens of the world.

\section{Notes}

${ }^{1}$ Raymond Vernon, “Economic Sovereignty at Bay," Foreign Affairs 47, no. 1 (October 1968): 110.

${ }^{2}$ T. Miller, Globalization and Sport (London: Sage Publications, 2001).

${ }^{3}$ Stephen J. Korbin, "Sovereignty@Bay: Globalization, Multinational Enterprise and the International Political System," in The Oxford Handbook of International Business, eds. Alan Rugman and Thomas Brewer (Oxford: University Press, 2001).

${ }^{4}$ Arjun Appadurai, Modernity at Large: Cultural Dimensions of Globalization (Minneapolis: University of Minnesota Press, 1996).

${ }^{5}$ George W. Ball, “The Promise of the Multinational Corporation,” Fortune 75 (June 1967): 80.

${ }^{6}$ J.L. Chappelet and B. Kubler-Mabbott, The International Olympic Committee and the Olympic System (Oxford: Routledge, 2008).

${ }^{7}$ Chris Green, Every Boy's Dream: England's Football Future on the Line (London: A \& C Black Publishers, 2009).

${ }^{8}$ Simon Kuper and Stefon Szymanski, Soccernomics (New York: Nation Books, 2009).

${ }^{9}$ Chris Green, Every Boy's Dream: England's Football Future on the Line (London: A \& C Black Publishers, 2009).

${ }^{10}$ Simon Kuper and Stefon Szymanski, Soccernomics (New York: Nation Books, 2009).

${ }^{11}$ J. Maguire, "Preliminary Observations on Globalization and the Migration of Sport Labor," Sociological Review 42, no. 3 (1994): 460. 
${ }^{12}$ Simon Kuper and Stefon Szymanski, Soccernomics (New York: Nation Books, 2009).

${ }^{13}$ Stephen J. Korbin, "Sovereignty@Bay: Globalization, Multinational Enterprise and the International Political System," in The Oxford Handbook of International Business, eds. Alan Rugman and Thomas Brewer (Oxford: University Press, 2001). 